DOI: https://doi.org/10.47405/aswj.v5i2.141

\begin{tabular}{|c|}
\hline $\begin{array}{c}\text { Asian Social Work Journal (ASWJ) } \\
\text { JOURAAL WORK } \\
\text { (ASW) }\end{array}$ \\
Volume 5, Issue 2, July 2020 \\
\hline \\
\hline
\end{tabular}

\title{
The Relationship Between Perception and Social Conflict in Society: Islam Hadhari in Malaysia
}

\author{
Darni Yusna ${ }^{1}$, Reza Fahmi $^{1}$, Prima Aswirna ${ }^{1}$ \\ 1Universitas Islam Negeri Imam Bonjol, Padang, West Sumatera, Indonesia
}

Correspondence: Reza Fahmi (rezafahmi@uinib.ac.id)

\begin{abstract}
The research objectives: (1) Explain the history of the development of Islam in Malaysia, (2) explain the picture of the spread of the standard positive perception of religious leaders and community members about Islam Hadhari, (3) connecting between positive opinions of religious leaders and community members and their relation to social conflicts in Malaysia. The study used a quantitative approach. The population in this study was 200 people, of which 48 were religious leaders, and 152 were members of the community. The data collection technique was using a psychological scale. Data analysis technique using Pearson correlation. The results of this study found that generally, the positive perceptions of religious leaders and community members about Islam Nusantara and Islam Hadhari were classified as high while the social conflict during society is classified as low.
\end{abstract}

Keywords: religious leaders, community members, Islam Hadhari, social conflict

\section{Introduction}

Rectification of Negative Western views at that time can only be done through the development and development of Islamic civilization, which upholds universal values; honesty, justice, tolerance, harmony, peace, equality, and so on. This is among the benefits of local wisdom in Malaysia, which built through the Islam Hadhari which was conceived by Malaysia's 5th Prime Minister, namely Tum Abdullah Ahmad Badawi. Islam Hadhari in Malaysia is not just an abstract idea that is difficult to translate into the social fabric of Malaysian society. But it is an idea accompanied by a moral movement to build a positive image of Islam in the eyes of the world. Therefore, Islam Hadhari is an excavation of Malay, Chinese and Indian values that synergy into a "1 Malaysia" force developed as an embodiment of thought and behavior that attaches importance to the application of universal Islamic values.

When Islam Hadhari is a theory of government based on Islamic principles raised by the 5th Prime Minister in Malaysia Abdullah Ahmad Badawi (Al-Saggaf, Yeslam, Peter, 2015), Malaysian Prime Minister, the ten principles of Islam Hadhari are as follows: (1) Faith and piety in Allah (2) Fair and trustworthy government (3) Freedom and freedom of the people (4) Mastery of science (5) balanced and comprehensive economic development (6) level adequate living for all (7) Protection of the rights of minorities and women (8) moral and cultural integrity (9) Protection of the environment (10) Strong defense (Brummet, 2015). Islam Nusantara and Islam Hadhari is an understanding rooted in local culture (local wisdom)? However, acceptance in the form of support for its existence is also a reality in the community. Even so, the presence of rejection of its life is also an integral part. So, this becomes an interesting problem to be studied more deeply. Considering the refusal supported by the fatwa of the 


\section{Asian Social Work Journal (ASWJ), Volume 5, Issue 2, (page 44 - 48), 2020 DOI: https://doi.org/10.47405/aswj.v5i2.141}

Ulema or the support of Mass Organizations has the potential for social conflict, which would undoubtedly harm the people of Malaysia in general and Muslims in particular.

However, the problems of this research are: (1) What is the history of the development of Islam based on local wisdom (Islam Hadhari) in Malaysia?. (2) What is the average distribution category of positive perceptions and social conflicts in Malaysia related Islam Hadhari, (3) Is there a relationship between the knowledge of religious leaders (Ulama) and community members with social conflicts amid the common concerning local wisdom (Islam Hadhari) in Malaysia?

\section{Methods}

This research is an international collaborative study between the Imam Bonjol State Islamic University of Padang and the International Institute of Islamic Thought (IIIT) in Malaysia. The population in this study is religious leaders and community members. There were 48 religious leaders and 152 community members in Malaysia involved in this study. Research locations in Malaysia include: Kuala Lumpur Partnership Area, Selangor Darul Ehsan, Negeri Sembilan, and Malacca. Simple random location was selection (pure random) where each region is part of major cities in Malaysia. After this, research uses mixing methods (qualitative-quantitative methods). Data collection methods used is observation, psychological scale. The purpose of sampling is accidental sampling. Data collection techniques in this study using psychology scales. Data analysis technique was using the Statistical Package of Social Science Version 24. The statistical model used in this study is the Pearson correlation to analysis the relationship between variables.

\section{Result and Discussion}

The characteristics of respondents were categorized on gender, age, occupation, income. Its described on Tabel 1 below:

Table 1: Basic Information About Respondents

\begin{tabular}{cllcc}
\hline Country & & Category & Sum & Percentage \\
\hline Malaysia & Gender & Male & 152 & 76.00 \\
& & Female & 48 & 24.00 \\
& Sum & & $\mathbf{2 0 0}$ & $\mathbf{1 0 0 . 0 0}$ \\
& Age & 20 years - 30 years old & 68 & 34.00 \\
& & 31 years - 41 years old & 79 & 39.50 \\
& Sum & $\geq 42$ years old & 53 & 26.50 \\
& & $\mathbf{2 0 0}$ & $\mathbf{1 0 0 . 0 0}$ \\
& Occupation & Civil Servants & 57 & 28.50 \\
& & Non Civil Servant & 143 & 71.50 \\
& Sum & & $\mathbf{2 0 0}$ & $\mathbf{1 0 0 . 0 0}$ \\
& Income & S \$ USD 1500 & 38 & $7: 00$ p.m. \\
& & \$ USD 3,000 4,500 & 59 & 29.50 \\
& & $\geq$ \$ USD. 6,000 & 103 & 51.50 \\
\hline Total Sum & & & $\mathbf{2 0 0}$ & $\mathbf{1 0 0 . 0 0}$ \\
\hline Sour
\end{tabular}

Source: 2019 Research Results

Based on the data in Table 1 above, it is found that the majority of respondents in Indonesia are male. Then the age range of most respondents is $\geq 42$ years. (in the category of developmental psychology, they are classified as middle adulthood). While the income aspect obtained a description that they typically earn less than USD 1,000, - USD 2,000 (low, middle social class).

Furthermore, based on the above data, it is obtained that the majority of respondents in Malaysia are male. Then the age range of most respondents is 31-41 years old. (in the category of developmental 
psychology, they are classified as young adults). Furthermore, the occupations owned by respondents generally work in the private or entrepreneurial sector. While in the aspect of income, it is obtained that typically they earn more than USD 6,000. (in the context of social class, respondents come from uppermiddle social class Society). Based on the results of the validity and reliability test using Cronbach alpha obtained reliability values of 0.817 (Positive Perception) and 0.826 (Social Conflict) in Indonesia. While the reliability value of 0.831 (Positive Perception) and 0.845 (Social Conflict) in Malaysia, means that the reliability level of the instrument in the form of a psychological scale is quite reasonable and appropriate to use.

This test is needed to see the tendency of the average distribution of prejudices of religious leaders and community members about Islam Nusantara. Then what about the spread of min and the percentage of social conflicts that occur in society. This can be seen in Table 2 below:

Table 2: Average Distribution and Percentage of Positive Perceptions and Social Conflicts About Islam Hadhari

\begin{tabular}{llll}
\hline Variable & Category & Sum & Percentage \\
\hline Positive Perception & High & 111 & 55.50 \\
& Low & 89 & 44.50 \\
Social Conflict & High & 37 & 18.50 \\
& Low & 162 & 81.50 \\
\hline
\end{tabular}

Based on Table 2 above, it is found that, in general, perceptions among religious leaders and community members in Malaysia about Islam Hadhari are high 111 (55.50\%). While the social conflict in the community is relatively low, at $37(18.50 \%)$, this means that the perception of community leaders and members of the general public towards Islam Hadhari is good, where they assume that Islam Hadhari is not charged with royal political propaganda to carry out work programs that the kingdom wants to implement. So that Islam Hadhari has no political nuance with the aim of "pushing" the interests of the country (government), especially through the scientific studies with an Islamic approach. So that Islam is not misused for political purposes by the kingdom, however, the view of Islam Hadhari from religious leaders and community members in Malaysia has brought about a relatively low social conflict, which is $162(81.50 \%)$. This means that the views of religious leaders and community members about Islam Hadhari, in general, are positive that it does not have the potential to cause social conflict among religious leaders and community members in Malaysia.

Based on the previous explanations above, it is obtained that the development of Islam Hadhari has its pattern where it develops in harmony with the development of Islamic history in the Southeast Asian country, where Islam Nusantara tries to maintain local culture. At the same time, Islam Hadhari developed the value of "1Malaysia" as a national base. And in the end, it shows the existence of local wisdom on the presence of Islam Hadhari, which is guided by three elements: (1) No determination is made between Islamic values and local culture. (2) The implementation of Islamic values that follow the progress of Science and Technology. (3) Islamic values developed to enrich universal socio-cultural values.

Table 3: Correlation Between Perceptions and Social Conflicts About Islam Hadhari

\begin{tabular}{llll}
\hline Variable & & Positive Perception & Social Conflict \\
\hline Positive Perception & Pearson Correlation & 1 & $-0,616\left(*^{*}\right)$ \\
& Sig. (2-tailed) & & .000 \\
& N & 200 & 200 \\
Social Conduct & Pearson Correlation & $-0.316(* *)$ & 1 \\
& Sig. (2-tailed) & .000 & \\
& N & 200 & 200 \\
\hline
\end{tabular}

** Correlation is significant at the 0.01 level (2-tailed). 
DOI: https://doi.org/10.47405/aswj.v5i2.141

Based on the analysis in Table 6 above, obtained a description that the correlation test of Pearson (product-moment) found $r$ count is - 0 .616. In contrast, the value of $r$ table is 0.195 . So, $r$ count $<r$ table, $\mathrm{Ho}=$ Rejected, meaning that there is a significant negative relationship between positive perceptions of religious leaders and community members with social conflicts about Islam Hadhari. Where the favorable opinion of religious leaders and members of the community will bring low social strife, conversely, if the positive perceptions of religious leaders and community members are low, it will be able to increase (high) social conflict between religious leaders and community members about Islam Hadhari. Given the spread of the mean or mean classified as high on the positive perception variable, while the way or indicate on the variable social conflict is low. This means that the spread of ideas and studies on Islam Hadhari has been accepted by most religious leaders and community members in Malaysia so that it does not cause social conflict. Thus, Islam Hadhari in Malaysia is seen as a moderate Islam and is not concerned only with the interests of specific groups (Malay) who are under the Islamic religion. Islam Hadhari provides an opportunity to dialogue and thinking about the progress of the Malaysian Nation, without egoism and arrogance in building a multicultural country.

\section{Conclusion}

Islam Hadhari is considered by most religious leaders and community members in Malaysia to be social and thought movement that wants to continue to apply the values of Islam that are Rahmatan Lilalamin (Blessing for the universe) and continue to develop along with the development of a dynamic society. Thus Muslim scientists and scholars in Malaysia supported the royal (government) policy to develop Islam Hadhari is more because they think that Islam Hadhari is the answer to the negative stigmatization of Western countries over their leading Muslims after the dark events (Black September 9/11) a few years ago in the United States. While the Islam Hadhari (Malaysia) was built from the spirit of building a national character that is "biased or multicultural with the philosophy of 1 Malaysia" or a variety of arts and cultures and religions that grow in Malaysian society, this must be understood that given that as a nation-state (nation-state) consists of three diverse cultural elements; Malay, Chinese and Indian. Therefore Islam Hadhari in Malaysia places great importance on "United Malaysia Values," namely Islam that is tolerant and respects each other as nationals. Even though Malays were the majority ethnic group in this neighboring country at the time, this did not mean that the ethnic Malays wanted to dominate the royal (government) policy by only prioritizing their ethnic interests. But Malay, as an ethnic majority, also accommodates the importance of ethnic Chinese and Indians as part of the "1 Malaysia" initiated by the kingdom. Secondly, the term Islam Nusantara and Islam Hadhari carry the same local wisdom, which is prioritizing a peaceful life, respecting differences and upholding human rights. So that Islam Hadhari (Malaysia) and Islam Nusantara (Indonesia) need to be supported and developed better so that the spirit of Islamic moderation that grows and advances in the community builds a positive Islamic image and at the same time provides benefit to all humankind. Third, Islam Hadhari are colored by the history of the development of the same Islam, namely Islam entered without violence. Where Islam coexists with the culture of the local community, this means that Islam does not clash with community cultural values. But synergize in building a harmonious civilization with an active principle of moderation. Even so, the practice of "Syrik or kurafat" remains also a concern, which is also opposed firmly and consistently in the development of Islam Nusantara in Indonesia and Islam Hadhari in Malaysia. Fourth, Islam Hadhari (Malaysia) and Islam Nusantara (Indonesia) provide ample scope in the development of Islamic civilization. So that Islam Nusantara has been translated into various joints of social life. For example, Gymnastics or Islam Nusantaraic sports, mosque building architecture that reflects the Islamic Nusantara, and so on, whereas the development of Islamic Hadhari has been implemented in the world of journalism, the development of Islamic Science and so on.

The fifth Islam Hadhari (Malaysia) is not a new ideology or ism, but a sincere and istiqomah (consistently) effort to build a positive and progressive Islamic image, by promoting moderation values that uphold human rights and equality and harmony in the life of the nation and state. Therefore Islam Hadhari (Malaysia) and Islam Nusantara (Indonesia) were born not to need to be debated in the context of "terms" or other insubstantial trivial issues. However, it is studied further and in-depth so that Islam can avoid the stigma of radical Islam and intolerant Islam from components of other nations with 
different ethnic groups and religions and races in the two sovereign countries. Sixth that the Islamic Archipelago (Indonesia) and Islam Hadhari (Malaysia) are characteristic of a nation-based Islamic moderation. Wherein it contains nationalism in each country. It's just that Indonesia has implemented nationalism since 1928. It means that Indonesia discussed nationalism nationally long before Malaysia spoke "1 Malaysia". It means that Indonesia builds national character first and then builds economic growth. Considering the nationalism of nationalism in Malaysia was made by first developing prosperity (economy) for the community of people (Chinese, Indian, and Malay) in Malaysia. After the country is "prosperous," a proud national awareness is developed for the country (Malaysia). It is not surprising when building a public image through the pride of the development being carried out. For example: Building the tallest twin towers in the world, creating the largest mall in Asia, and so on.

\section{References}

Allen, J. (2007). "Aristotle on the Disciplines of Argument: Rhetoric, Dialectic, Analytic" In Rhetorica 25: 87-108.

Al-Saggaf, Yeslam \& Peter Simmons. (2015). Social media in Saudi Arabia: Exploring its use during two natural disasters. Technological Forecasting and Social Change, 95.

Brummet, B. (2015). Rhetoric in Popular Culture, Fourth Edition. UK: Sage Publication Ltd

Fahmi, R., Aswirna, P \& Nurdin, S. (2019). The Exploration Study about Local Wisdom: Islam Nusantara-Islam Hadhari. Proceedings Conference. 19th Annual International Conference on Islamic Studie (AICIS)s. Jakarta: Indonesian Religious Affairs Department.

Ruben Brent, D. \& Lea P Stewart. (2006). Communication and Human Behavior. United States: Allyn and Bacon

Lunsford, Andrea A, Kirt H. Wilson dan R. Eberly (eds.) .(2009). The SAGE Handbook of Rhetorical Studies. UK: Sage Publication Ltd.

Mohamed Sharif Bashi. (2018). Islam Hadhari: Concept and Prospect. Researchgate. Accessed August $20,2018)$

Miski Mudin. (2019). Virtual Islam. Yogyakarta: Bidung Publisher.

Nurdin, S., Fahmi R, \& Aswirna, P. (2019). Exploration Study about Local Wisdom: Islam Nusantara and Islam Hadhari in Indonesia- Malaysia. Book unpublished. Jakarta: Indonesian Religious Affairs Department.

Romzek, B. S. (2015). Living Accountability: Hot Rhetoric, Cool Theory, and Uneven Practice. Political Science \& Politics, 48(1), 27-34. 